\title{
A developing country perspective on recent developments in animal breeders and intellectual property rights
}

\author{
M.M. Scholtz ${ }^{1,2 \#}$ and J. Mamabolo ${ }^{3}$ \\ ${ }^{1}$ Post Graduate School in Animal Breeding, University of the Free State, P.O. Box 339, \\ Bloemfontein 9301, South Africa \\ ${ }^{2}$ ARC - Animal Production Institute, Private Bag X2, Irene 0062, South Africa \\ ${ }^{3}$ Department of Agriculture, Private Bag X138, Pretoria 0001, South Africa
}

\begin{abstract}
Animal breeding and genetics have changed markedly, resembling those that have already taken place in the plant sector. These changes are going to be larger with sequenced genomes, transgenic livestock and cloned animals. Animal scientists have now started to protect their intellectual property and these protective measures have alarmed other scientists and the public. The challenge for developing countries is to guard against bio-piracy of their indigenous animal genetic resources, and to safeguard technologies that they have been using. A second concern is the export of genetic material to countries that did not ratify the Convention on Biodiversity. The first operational conflict resulted from a patent on a "Method of Bovine Herd Management". The patent claims rights to a practice that has been public knowledge for nearly 100 years. The novel idea within the patent is the specific mathematical model and procedures developed for analysis of test day yields. Monsanto has recently applied for a series of patents on pig breeding in some 160 countries, whereas researchers in New Zealand and Australia obtained a patent for the Booroola gene. The east African Boran cattle breed has also been patented in Australia. Currently developing countries risk losing their intellectual property on indigenous livestock while research institutions require a stable regulatory framework in which to operate. There should be a balance between the needs of developed and developing countries and interim measures should be put in place in anticipation of the development of a legal framework on animal genetic resources.
\end{abstract}

Keywords: Animal genetic resources, animal breeders’ rights, intellectual property

\# Corresponding author. E-mail: elsabe@arc.agric.za; ${ }^{2}$ Corresponding address

\section{Introduction}

Animal breeding and genetics have changed markedly in the $20^{\text {th }}$ Century and the changes in the $21^{\text {st }}$ Century are going to be even larger with sequenced genomes, transgenic livestock and cloned animals. Animal scientists at universities and research institutions have now also started to protect their inventive work through patenting. This has alarmed and threatened the general public and raised economic, legal and ethical concerns (Rothschild et al., 2003).

The increased exploitation of animal genetic resources from developing countries is also becoming a major concern. The need for a legal framework on animal genetic resources was first discussed during the World Food Summit in June 2002. At the Commission on Genetic Resources for Food and Agriculture in 2004 the issue was raised again, but some developed countries objected. Any further discussion was postponed until 2007, when the first report on the State of the World's Genetic Resources will be completed (Köhler-Rollefson, 2005).

Intellectual property (IP) results from the creative or inventive work of an individual or individuals. IP includes copyrights, trademarks, trade secrets and patents, which can be summarized as follows (Rothschild, 2002):

(1) Copyright protects IP such as articles, books, web pages, computer software and music, and applies when the work is in a publishable form. The symbol (c) is not required, but is recommended for enforcement of rights.

(2) Trademarks are used primarily to identify the source of the goods, products or services. The TM claims common law trademark rights, while the ${ }^{\circledR}$ indicates registration. 
(3) Trade Secrets represent IP that is not divulged by the owner and confers some competitive advantage. It can last as long as the information is kept secret.

(4) Patents represent the largest form of IP and their development is regulated by laws differing from country to country. These laws and their interpretations are subject to change, especially when new technologies are introduced. A patent represents a legal monopoly granted by a country's government to an inventor, permitting the patent owner to prohibit anyone else from making, using or selling this invention for a specific period of time (now generally 20 years).

\section{Discussion}

The following are some examples illustrating the conflicts that have already been manifested in animal breeding. One of the first conflicts in quantitative animal breeding resulted from a patent entitled "Method of Bovine Herd Management" granted to the Cornell Research Foundation (Cornell University) in the USA in 1994 and Canada in 1998. The invention is for the "test-day model" and includes the gathering of data, mathematical treatment and the use of the data by dairy producers (Rothschild et al., 2003). The novelty and unobviousness of the patent has been seriously questioned. The practices of gathering, manipulating and using data by dairy producers have existed for nearly 100 years (Schaeffer, 2002). In South Africa, these principles have been in use since 1917. The patent therefore claims rights to a practice that has been public knowledge for a long time. The novel idea within the patent is the specific mathematical model and procedures that were developed for the analysis of test day yields. The patent limits any organisation from collecting, analyzing and dispensing results without permission or royalties being paid to the patent holder.

Monsanto has applied for a series of patents on pig production in some 160 countries. The Monsanto (USA) patent applications were published in February 2005 at the World Intellectual Property Organisation in Geneva. It seems that Monsanto is seeking patents not only on methods of breeding, but on actual breeding herds of pigs as well as on the offspring that result. Details of the patent are available at http://www/greenpeace.org/international/news/Monsanto-pig-patent-111. There seem to be two groups of patents under consideration, namely:

(1) A method of increasing an animal's average genetic merit comprising the utilization of Quantitative Trait Loci (QTL's) and molecular genetic markers of interest for the QTL's. It also includes using Marker Assisted BLUP (MA-BLUP) where animals are ranked according to their EBV (Estimated Breeding Value) for selected molecular genetic markers and quantitative traits; and

(2) Breeding plans, a pig herd, growth, meat quality, reproduction and health traits, including methods of crossbreeding and selection using artificial insemination and other breeding methods (which are already in use). The main "invention" is nothing more than a particular combination of these elements designed to speed up the genetic gain for selected traits. Patenting is not only for the methods, but also for the actual pigs that are bred from these methods.

In 2003 researchers from New Zealand and Australia obtained a patent for the Booroola gene (USA application no 10/169,051). This happened in spite of general belief / agreement that genes cannot be patented. The Booroola gene in Australia, which has a large effect on litter size of sheep, can be traced back to Bengal sheep which were imported from Calcutta and crossed with Merinos (Köhler-Rollefson, 2005).

The South African Patents Act (Act no 57 of 1978) (Section 24(a)(b)) states that a patent shall not be granted for any variety of animal or plant or any essentially biological process for the production of animals or plants, not being a microbial process or the product of such a process. Consequently, animals and animal varieties per se are not patentable in South Africa.

In the case of Australia it was ruled that merely the fact that organisms were living was not a barrier to their patentability. In terms of patentability of higher life forms, such as animals, they are not treated any differently by the Australian Patent Office from the way in which lower life forms are treated (Blattman et al., 2002). This is probably the reason why the East African Boran cattle breed could be patented in Australia, as reported in the Farmer's Weekly of 10 March 2006.

The practice in New Zealand is similar to that of the Australian Patent Office. In general patents to animals are also allowable in Japan. In contrast to these countries, animals (whether transgenic or otherwise) are not patentable in countries such as Argentina, Brazil and China (Blattman et al., 2002).

It is clear that the issue of the patentability of animals will continue to be debated. However, it now becomes a real danger that animal genetic material from developing countries may be exploited by developed countries and large international companies. The development of an "International Framework on 
Animal Genetic Resources” is therefore becoming a matter of urgency. Since the International Treaty on Plant Genetic Resources was signed there have been moves to negotiate an equivalent agreement for animal genetic resources (Köhler-Rollefson, 2005). There is a strong rationale for a legal framework to create the appropriate utilization of animal genetic resources. However, some developed countries are reluctant to enter into such negotiations.

Developing countries have put forward the following arguments for developing an equivalent treaty for animal genetic resources (Köhler-Rollefson, 2005):

(1) Animal genetic resources are a global concern. They are essential to achieve food security and to ensure sustainable livelihoods.

(2) Domestic animal diversity is essential for future generations to develop breeds adapted to largely unforeseeable ecological and economical scenarios. Farm animal genetic resources form the raw material that farmers depend on to adapt to changes in the natural environment and in production conditions.

(3) The conservation of animal genetic resources needs to be promoted and much more awareness about the issue raised.

(4) Biotechnology is advancing rapidly, and huge sums are being channelled into studies of livestock genomes. This is happening in a legal vacuum. Livestock holders risk losing their intellectual property rights, while biotechnology firms require a stable regulatory framework in which to operate.

(5) The Convention on Biological Diversity requires "access and benefit-sharing". It needs to be examined whether these concepts are applicable in any meaningful way to the situation of animal genetic resources.

(6) An international instrument is necessary to ensure compliance with rules that may be agreed upon.

(7) A legal instrument, and the negotiations leading up to it, could be a means of leveraging funds for the conservation of animal genetic resources.

\section{Conclusion and recommendations}

There should be a balance between the needs of developed and developing countries, since developed countries do not necessarily need the same agreements that the developing countries do. Developing countries should, however, guard against bio-piracy of livestock (which has happened with plants), otherwise they could loose their IP Rights.

The first example of plants is Pelagorium and Geranium (commonly known as malvas) which are indigenous genera to South Africa. Soon after the establishment of the refreshment station at the Cape in 1652, many explorers and botanists collected plant material from the rich Cape flora and took them to Europe where extensive breeding has been done and cultivars commercialized, with no benefit going back to South Africa in any way. It has been so well developed and marketed in Europe that few people really know that these two genera are not European flowers, but in fact South African. Another example is Eragrostis curvula which was collected in South Africa by botanists during the 1950's and exported to the USA where it was improved. South Africa is now importing Eragrostis curvula seed from Texas.

Developing countries should consider a ban on the export of any farm animal genetic resources to countries that did not ratify the Rio Convention on Biodiversity, and specifically the genetic biodiversity treaty on benefit sharing. The real issue is whether international companies or organizations should be allowed to sample livestock from developing countries, and to subsequently make money by selling them to both developed countries and back to developing countries from where they were obtained. South Africa should establish which countries did not ratify the genetic biodiversity treaty, and consider putting a moratorium on the export of genetic material of landrace breeds to these countries, using the regulations of the Animal Improvement Act (Act no 62 of 1998). In terms of the Act "landrace" means a specified breed of a kind of animal indigenous to or developed in the Republic (of South Africa). Property right issues related to biodiversity protection and conservation in South Africa are currently managed under the Biodiversity Act (Act no 10 of 2004) by the Department of Environmental Affairs and Tourism.

A treaty / agreement / policy should also be developed to protect genetic material from being distributed to other countries after export to one country. Examples are the Boer Goat that has been exported from South Africa to Australia and from there to China as well as their export to Canada and from there to the USA where they are promoted as the Texas Redhead. Such policy could include the establishment of international breed societies with acknowledgement of source, material transfer agreements, etc. 
Clear definitions from an agricultural perspective are needed on indigenous people and livestock and how the rights of indigenous people on their breeds, and benefit sharing in the originating countries, should be approached.

Livestock keepers (of indigenous animals) should be supported in terms of service delivery to recognise the value of livestock keepers in the conservation of animal genetic resources. In some European Union countries livestock keepers are paid a subsidy / levy if they maintain certain animal genetic resources.

Sustainable rural livelihoods should be supported and enhanced through new and novel markets for the products of indigenous farm animals so that the owners benefit financially. Such products should be recorded and collated on a database. Indigenous knowledge related to animal husbandry and breeding practices should also be documented and captured in order to protect it. Initiatives to amend the Patents Act of South Africa should include issues related to prior knowledge in respect of indigenous knowledge systems.

The issue of protecting IP in animal science should receive urgent attention from developing countries. Such protection can be in various forms, e.g. patents, designs, copyrights, trademarks, trade practices, domain names, appellation of origin, etc. The ARC-Animal Production Institute in South Africa is currently trade marking a number of activities to identify the source of goods, products or services, and to prohibit other parties to infringe on them.

\section{References}

Blattman, J., McCann, J., Bodking, C. \& Naumsoka, J., 2002. Global intellectual property : International developments in animal patents. In: Intellectual Property Rights in Animal Breeding and Genetics. Eds. Rothschild, M.F. \& Newman, S., CABI Publishing, New York. pp. 63-84.

Schaeffer, L.R., 2002. Dairy cattle test day models: A case study. In: Intellectual Property Rights in Animal Breeding and Genetics. Eds. Rothschild, M.F. \& Newman, S., CABI Publishing, New York. pp. 233246.

Köhler-Rollefson, I., 2005. An international legal framework on animal genetic resources or food and agriculture. In: Building and International Legal Framework on Animal Genetic Resources. Ed. Mundy, P., ICS Bergisch Gladebach, Bonn. pp. 21-24.

Rothschild, M.F., 2002. Patenting of gentic innovations in animal breeding. Proc. $7^{\text {th }}$ Wrld. Congr. Genet. Appl. Livestock Prod. 29, 25-32.

Rotschild, M.F., Plastow, G. \& Newman, S., 2003. Patenting in animal breeding and genetics. World Association for Animal Production: Book of the Year. pp. 269-278. 